\title{
Ефективність впливу дієтичної добавки «Лептин Менеджер" на зниження маси тіла у жінок з різними генотипами за геном рецептора до лептину, які займаються силовим фітнесом
}

\author{
УДК 796.035+796.412:615.874.2-055.2 \\ С. Б. Дроздовська ${ }^{1}$, О. Л. Палладіна ${ }^{1}$, С. Д. Юрьєв ${ }^{3}$, \\ А. О. Поліщук', С. В. Гончаров ${ }^{2}$, В. Є. Досенко ${ }^{1,2}$
}

${ }^{1}$ Національний університет фізичного виховання і спорту України, Київ, Україна

${ }^{2}$ Інститут фізіології ім. О. О. Богомольця НАН України, Київ, Україна

${ }^{3}$ Національний медичний університет ім. О. О. Богомольця, Київ, Україна

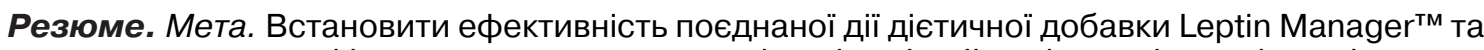
програми силового фітнесу на зниження маси тіла жінок I та II періоду зрілого віку з різними генотипами. Методи. У дослідженні, яке тривало 3 міс., взяли участь 62 жінки II періоду зрілого віку з надлишковою масою тіла (IMT $\geq 25)$, з них до експериментальної групи увійшла 21 жінка, яка брала участь у тренувальній програмі з силового фітнесу на фоні одночасного прийому препарату «Лептин Менеджер» (Xymogen, USA). Контрольну групу склали 17 жінок, котрі займалися силовим фітнесом і не приймали препарат, та 24 жінки, які не займалися фітнесом. Тренування було побудовано за системою Crossfit, функціонального тренінгу та включало роботу на тренажерах (блочні та важельні пристрої) за системою Full-body у кожному тренуванні. Q223R поліморфізм гена рецептора до лептину (LEPR) визначали методом полімеразної ланцюгової реакції (ПЛР) у реальному часі. Визначення лептину проводили ензимним імунозв'язуючим імуносорбентним методом, визначення композиційного складу тіла - методом біоімпедансометрії за допомогою приладу «Tanita». Результати. Рівень лептину у жінок з надмірною масою тіла характеризується широким діапазоном, що перевищує норму у бік низьких, так і високих концентрацій: у $4 \%$ жінок рівень цього гормону нижчий від норми, а у 36 \% - вищий від норми. Показник лептину у жінок-носіїв Q-алеля вдвічі вищий, ніж у жінокносіїв R/R-генотипу $(p=0,045)$. Встановлено тісний лінійний зв'язок між рівнем лептину і такими показниками, як індекс маси тіла $(r=0,7)$ і вміст жирової тканини $(r=0,73)$; середнього ступеня зв'язок між рівнем лептину і масою тіла $(r=0,65)$. Поєднаний вплив тренувальної програми силового фітнесу та вживання препарату «Лептин Менеджер» призводить до більш значних змін антропометричних показників, композиційного складу тіла жінок з надмірною масою тіла порівняно з контрольною групою. Найбільш виражені зміни у композиційному складі тіла відбулися у жінок з R/R-генотипом гена LEPR. Вживання препарату «Лептин Менеджер» призводить до зменшення рівня лептину: в експериментальній групі - на 33,4 \% ( $>$ < 0,05), у контрольній - на 6,1 \%. Висновки. Q223R поліморфізм гена LEPR може слугувати молекулярно-генетичним маркером лептинової резистентності. Q-алель Q223R поліморфізму гена $L E P R$ сприяє розвитку ожиріння. $\mathrm{R}$-алель та $\mathrm{R} / \mathrm{R}$-генотип гена $L E P R$ - зниженню рівня цього гормону після фізичних навантажень. Вживання препарату «Лептин Менеджер» на фоні фізичних навантажень призводить до вірогідного зменшення рівня лептину порівняно 3 контрольною групою.

Ключові слова: лептин, силовий фітнес, поліморфізми гена рецептора лептину, «Лептин Менеджер», надлишкова маса тіла. 
Эффективность влияния диетической добавки «Лептин Менеджер» на снижение массы тела у женщин с разными генотипами по гену рецептора к лептину, занимающихся силовым фитнесом

С. Б. Дроздовская, О. Л. Палладина, С. Д. Юрьев, А. А. Полищук, С. В. Гончаров, В. Е. Досенко

Резюме. Цель. Установить эффективность сочетанного действия диетической добавки Leptin Manager ${ }^{\mathrm{TM}}$ и программы силового фитнеса на снижение массы тела женщин I и II периода зрелого возраста с разными генотипами. Методы. В исследовании, которое длилось 3 мес., приняли участие 62 женщины II периода зрелого возраста с избыточной массой тела (ИМТ $\geq 25$ ), из них в экспериментальную группу вошла 21 женщина, которая принимала участие в тренировочной программе по силовому фитнесу на фоне одновременного приема препарата «Лептин Менеджер» (Xymogen, USA). Контрольную группу составили 17 женщин, занимавшихся силовым фитнесом и не принимавших препарат, и 24 женщины, которые не занимались фитнесом. Тренировки были построены по системе Crossfit, функционального тренинга и включали работу на тренажерах (блочные и рычажные устройства) по системе Full-body в каждой тренировке. Q223R полиморфизм гена рецептора лептина $(L E P R)$ определяли методом полимеразной цепной реакции (ПЦР) в реальном времени. Определение лептина проводили энзимным иммуносвязывающим иммуносорбентным методом, определение композиционного состава тела - методом биоимпедансометрии с помощью прибора «Tanita». Результаты. Уровень лептина у женщин с избыточной массой тела характеризуется широким диапазоном, превышающим норму в сторону как низких, так и высоких концентраций: у 4 \% женщин уровень этого гормона ниже нормы, а 36 \% - выше нормы. Показатель лептина у женщин-носителей Q-аллеля в два раза выше, чем у женщинносителей RR-генотипа ( $p=0,045)$. Установлена тесная линейная связь между уровнем лептина и такими показателями, как индекс массы тела $(r=0,7)$ и содержание жировой ткани $(r=0,73)$; средней степени связь между уровнем лептина и массой тела $(r=0,65)$. Совместное влияние тренировочной программы силового фитнеса и употребление препарата «Лептин Менеджер» приводят к более значительным изменениям антропометрических показателей, композиционного состава тела женщин с избыточной массой тела по сравнению с контрольной группой. Наиболее выраженные изменения в композиционном составе тела произошли у женщин с R/R-генотипом гена LEPR. Применение препарата «Лептин Менеджер» приводит к уменьшению уровня лептина: в экспериментальной группе - на 33,4 \% ( $<$ < 0,05), в контрольной - на 6,1\%. Выводы. Q223R полиморфизм гена LEPR может служить молекулярно-генетическим маркером резистентности к лептину. Q-аллель Q223R полиморфизма гена LEPR способствует развитию ожирения, R-аллель и R/R-генотип гена LEPR - снижению уровня этого гормона после физических нагрузок. Применение препарата «Лептин Менеджер» на фоне физических нагрузок приводит к достоверному уменьшению уровня лептина по сравнению с контрольной группой.

Ключевые слова: лептин, силовой фитнес, полиморфизмы гена рецептора лептина, «Лептин Менеджер», избыточная масса тела.

Effects of the dietary supplement Leptin Manager on weight loss in women with different leptin receptor genotypes in strength fitness

S. B. Drozdovska, O. L. Palladina, S. D. luriev, A. O. Polishchuk, S. V. Honcharov, V. I. Dosenko

Abstract. Objective. To determine the effectiveness of combined action of Leptin Manager ${ }^{\mathrm{TM}}$ dietary supplement and strength fitness programs for reducing the body weight of women of the $1^{\text {st }}$ and $2^{\text {nd }}$ period of mature age with different genotypes. Methods. In the study, which lasted 3 months, 62 women of the second period of the mature body with excessive body mass (BMI $\geq 25)$ took part. Of them 21 women constituted the experimental group, which participated in strength fitness training program along with simultaneous administration of "Leptin Manager" preparation (Xymogen, USA). The control group comprised 17 women who were engaged in strength fitness and did not take the preparation, and 24 women who were not engaged in fitness training. The training was built on the Crossfit system, a functional training and included work on simulators (block and lever devices) according to the Fullbody system at each training session. The Q223R polymorphism of leptin receptor gene (LEPR) was determined by the method of polymerase chain reaction (PCR) in real time. Determination of leptin was carried out by enzyme immunobinding immunosorbent method, whereas that of body composition - by bioimpedansometry with the help of the "Tanita" device. Results. Leptin level in overweight women is characterized by a wide range that exceeds the norm for both low and high concentrations: in $4 \%$ of women, the level of this hormone is lower than normal, and in $36 \%$ is higher than normal. Leptin index in women carriers of $Q$-allele is twice as high as that in female carriers of the $R / R$ genotype $(p=0.045)$. A close linear relationship was established between leptin level and such indices as body mass index $(r=0.7)$ and adipose tissue content $(r=0.73)$; and a moderate correlation between leptin level and body weight $(r=0.65)$. The combined effect of strength fitness training program and the use of "Leptin Manager" leads to more significant changes in anthropometric indices, body composition of 
women with excessive body weight as compared to the control group subjects. The most pronounced changes in the body composition occurred in women with the $\mathrm{R} / \mathrm{R}$ genotype of the LEPR gene. The usage of "Leptin Manager" results in decreased leptin level: in the experimental group - by 33,4\% ( $p<0,05)$, in the control group - by 6,1\%. Conclusions. The Q223R polymorphism of the LEPR gene can serve as a molecular genetic marker of leptin resistance. Q-allele Q223R polymorphism of the LEPR gene promotes the development of obesity. R-allele and the $\mathrm{R} / \mathrm{R}$-genotype of the LEPR gene reduce the level of this hormone after exercise. The usage of "Leptin Manager" preparation in the face of physical loads leads to a possible decrease of leptin level as compared with the control group.

Keywords: leptin, strength fitness, polymorphism of leptin receptor gene, "Leptin Manager", excessive body mass.

Постановка проблеми. Однією з найактуальніших проблем сьогодення залишається надмірна маса тіла і ожиріння. У всьому світі спостерігається тенденція до зростання поширеності цього захворювання. Нині 39 \% населення планети віком понад 18 років має надлишкову масу тіла, $13 \%$ - ожиріння [35]. Згідно із звітом Всесвітньої організації охорони здоров'я 2017 р. у багатьох країнах європейського регіону спостерігається зростання кількості осіб, які страждають від ожиріння. Ожиріння набуло характеру епідемії та призводить до значного погіршення рівня здоров'я населення. В економічно розвинених країнах майже $50 \%$ населення має надмірну масу тіла, при цьому в 30 \% з них спостерігається ожиріння. В Україні від зайвої маси страждає кожна четверта жінка і кожен шостий чоловік. Всього від ожиріння страждає близько 15-20\% населення нашої країни [36].

Вважається, що інтенсивність метаболізму, наявність надлишкової маси тіла на 77 \% визначається генетично, і лише на 23 \% залежить від фракторів оточуючого середовища, в тому числі і від способу життя [31]. Відповідно до сучасних уявлень, патогенез ожиріння великою мірою (від 30 до $70 \%$ ) визначають генетичні фактори [2, 4, 6]. Такий показник, як окружність талії залежить від генетичних фракторів на $60 \%$, а індекс маси тіла - на $40 \%$. Існують чотири рівні генетичної детермінації ожиріння: генетичне ожиріння, сильна генетична схильність, слабка генетична схильність і генетична стійкість [16].

Ожиріння може обумовлюватися як моногенетично так і полігенетично, тобто одним геном або їх комплексом. Остання карта генів, що сприяють розвитку ожиріння, - «The Human Obesity Gene Map: The 2005 Update», опублікована у журналі OBESITY і містить список із 11 генів, мутації у яких призводять до ожиріння, і 50 локусів, що успадковуються за законами Менделя. Крім того, ця карта містить 253 локуси, що впливають на ожиріння $[22,23]$.

Дослідження, проведені у Великій Британії, оцінюючи внесок кожного алеля, що збільшує індекс маси тіла, у ймовірність розвитку ожиріння, дозволили отримати дані, які свідчать, що навіть великою мірою генетично обумовлене ожиріння можна на $40 \%$ зменшити з допомогою рухової активності [17]. Дослідники встановили, що кожний алель, який збільшує індекс маси тіла, посилює ожиріння у 1,158 раза у неактивних осіб, і в 1,116 раза - у фізично активних.

На розвиток ожиріння впливають також епігенетичні фактори, що обумовлюють ефективність роботи генів [9]. Більшість генів перебуває в організмі у вимкненому режимі, який контролюють метильні групи. Доведено, що істотне зниження рівня метилювання гена інсуліноподібного фрактора росту (IGF 2) спостерігається у дітей батьків, які страждають на ожиріння [27].

Покращення стану здоров'я при зниженні маси тіла неможливе без виконання фрізичних вправ. Встановлено, що обмеження кількості калорій після тривалої висококалорійної дієти на фоні відсутності фрізичних вправ, незважаючи на зменшення маси тіла та нормалізації чутливості до інсуліну, призводить до активації мережі генів трансформуючого фактора росту $\beta$, пов'язаної із ремоделюванням матриксу та пригніченням генів, що залучені до процесу розвитку та живлення м'язової тканин [19].

Відповідно до сучасних даних наукової літератури однією з причин ожиріння $\epsilon$ резистентність до лептину - гормону насичення. Можливою причиною резистентності до лептину називають поліморфізми гена рецептора до лептину (LEPR). У гені знайдено 23 тис. поліморфізмів [33]. Серед них чотири викликають патогенетичний ефект, обумовлюють дефріцит рецепторів лептину. Найбільш дослідженим стосовно лептинової резистентності $\epsilon$ Q223R поліморфізм. I хоча зміни рівня лептину під час фрізичного навантаження досліджувалися раніше, зміни його концентрації у крові після занять оздоровчим фрітнесом під впливом препарату «Лептин Менеджер» не вивчалися. Встановлення результативності зниження маси тіла у жінок з різним генотипом за Q223R поліморфізмом гена $L E P R$ дозволить розширити індивідуальний підхід до тренувального процесу при ожирінні. 
Аналіз останніх досліджень і публікацій. Нещодавно жирову тканину почали розглядати як ендокринну залозу, що продукує білковий гормон лептин [8]. За сучасними даними цей гормон не тільки відіграє провідну роль у регуляції енергетичного гомеостазу, але і $є$ плейотропним медіатором у широкому діапазоні нейроендокринних функцій [32]. Лептин - це білок з молекулярною масою 16 кД, що секретується адипоцитами у кров у змінній кількості і контролює масу жирової тканин шляхом стимуляції обміну речовин в організмі. Лептин синтезується переважно білою жировою тканиною. Рівень лептину сироватки корелює із загальним вмістом жиру в організмі. Розміри адипоцитів $€$ важливими детермінантами синтезу цього гормону: чим більші адипоцити, тим більше вони виробляють лептину. Крім того, лептин $є$ індикатором запасу енергії та медіатором іï̈ балансу [11].

Лептин як адипоцитозалежний гормон відіграє ключову роль у регуляції апетиту, пригнічуючи споживання їжі та збільшуючи енергетичні витрати, стимулюючи метаболізм і фрізичну активність до підтримки енергетичного балансу [14]. Дія лептину опосередковується через лептиновий рецептор, що належить до першого класу родини цитокінових рецепторів [7].

Вплив вправ на зміну рівня гормонів, що залучені до регуляції енергетичного обміну, відображено у дослідженнях змін рівня лептину, нестафріну-1 та іризину [3, 12]. Але результати досліджень впливу вправ на лептин $€$ непереконливими, оскільки деякі дослідники встановили зменшення рівня лептину [29], інші - збільшення [28], деякі констатували відсутність змін [21].

Аеробні вправи протягом 30 хв двічі на день (зранку і ввечері) три дні поспіль обумовлюють зміни рівня лептину як тренованих, так і нетренованих осіб. Але індивідуальні коливання рівня лептину після вправ були пов'язані не з безпосередньою стресорною дією вправ, а зі змінами в енергетичному балансі людей, які займаються. Тому після ранкового тренування рівень лептину збільшився у $13 \%$ осіб та зменшився - у $16 \%$, а після вечірнього - збільшився у $30 \%$ обстежуваних і зменшився - у 20 \% [1]. Згадане дослідження ставить під сумнів твердження, що лептин - це гормон, що індукується фрізичними вправами.

За даними естонських дослідників, рівень лептину й інсуліну в групі осіб з надлишковою масою значно вищий, ніж в осіб з нормальною масою тіла. Рівень лептину негативно корелював 3 V̈О 2 max в обох групах. Чим вищий рівень лептину, тим нижчі показники $\mathrm{V}_{2} \max$. Рівень лептину корелює з руховою активністю. Чим вища рухова активність, тим нижчий рівень лептину. Низька рухова активність в групі осіб з надлишковою масою пов'язана з рівнем лептину у крові [24].

Аеробні вправи протягом року у нетренованих осіб без надлишкової маси тіла викликали невірогідні коливання як у чоловіків, так і в жінок, пов'язані з тим, що маса жирової тканини у цих осіб змінилася незначно [26]

Декілька поліморфізмів гена лептину ( $L E P)$ та лептинового рецептора ( $L E P R)$ асоційовані 3 розвитком ожиріння [15]. Ці варіанти можуть модифікувати ефрект регулярних фрізичних вправ на різні ознаки, пов'язані з ожирінням, наприклад, глюкозний гомеостаз [13].

Поліморфізми гена рецептора лептину (LEPR). Ген, що кодує білок, - рецептор до лептину, розміщений у 3-й підсмузі 31-смуги (бенда) короткого плеча 1-ї хромосоми (1р31.3). Містить 24 екзони. Білок належить до родини цитокінових рецепторів. Найбільше експресується у печінці, ендометрії, жировій тканині, легенях. Складається з 220 кв (тисяч пар нуклеотидів). У гені знайдено 22993 поліморфізми [33], серед яких чотири викликають патогенетичний ефект, три - дефіцит рецепторів лептину. У деяких наукових оглядах поліморфізми цього гену відносять до найбільш інформативних генетичних маркерів метаболічних шляхів підтримки енергетичного балансу та змін композиції тіла у відповідь на тренувальні програми, поряд з такими маркерами, як поліморфізми генів FTO, MC4R, ACE, PPARG, LEP, ADRB2, ADRB3 [15].

Найбільш широко вивчено декілька 3 цих поліморфізмів. Встановлено, що варіанти гена $\angle E P R$ впливають на активність лептинового рецептора.

Q223R (rs1137101) характеризується заміною аденіну на гуанін у 668 положенні в 6 екзоні і призводить до заміни гліцину на аргінін у 223 положенні у білку (Gln223Arg). Інша фрорма запису с.668A > G (Q/R). Встановлено, що наведений поліморфрізм впливає на здатність рецептора зв'язуватись із лептином [5]. У різних дослідженнях виявлено різну частоту мінорного алеля (MAF), крім того, у цих дослідженнях різні алелі називають мінорними [34]. У дослідженнях японських вчених показано, що Q223R асоційований $з$ рівнем рухової активності. Так, особи $3 \mathrm{R} / \mathrm{R}$-генотипом демонстрували коротший час рухової активності і довший неактивний час [20]. Q223R поряд з rs1137100 (K109R) демонстрували асоціацію з індексом маси тіла (IMT) та ступенем ожиріння у жителів Індонезії. G-алель асоційований із більшим об'ємом м'язової маси, ніж у 
учасників з А/A-генотипом. Крім того, G-алель сприяв кращим змінам об'єму підшкірного жиру у відповідь на силові тренування [30].

У дослідженнях Queabec Family Study було встановлено, що Q223R тісно пов'язаний із жировою масою. Слабкий зв'язок було встановлено між цим поліморфізмом і IMT, безжировою масою та сумою шести шкірних складок. В осіб із меншим IMT носії алеля Q223 були на 4 кг легші у безжировій масі [5]. Серед осіб із вищим індексом маси тіла частіше зустрічаються особи з R-генотипом. B інших дослідженнях було показано, що FTO rs9939609 і LEPR rs1137101 поліморфізми батьків впливають на масу тіла та IMT новонароджених дітей [18]. Таким чином, Q223R може слугувати молекулярно-генетичним маркером лептинової резистентності і може сприяти розвитку ожиріння.

Але асоціація цих маркерів з ожирінням має етнічний характер. Так, у малазійців інформативність цих маркерів у зв'язку з ожирінням не підтверджено [10]. Але встановлено, що сумарно LEP A19G, G2548A і LEPR K109R, Q223R виявляють синергічний ефект на ожиріння. У дослідженнях мексиканської популяції [25] встановлено, що ні rs1137101, ні rs1137100 не асоційовані з ожирінням, але С алель Т/C поліморфізму (rs 1805134) характеризується такою асоціацією.

Зв'язок роботи 3 науковими програмами або практичними завданнями. Робота виконується згідно з темою фундаментального дослідження Міністерства освіти і науки України «Молекулярно-генетичні особливості адаптації серцево-судинної системи до інтенсивних фрізичних навантажень» на 2017-2019 рр. (номер держреєстрації 0117U002383) та темою 2.8 «Особливості соматичних, вісцеральних та сенсорних систем у кваліфрікованих спортсменів на різних етапах підготовки» відповідно до плану НДР НУФВСУ на 2016-2020 рр.

Мета дослідження - встановити ефективність поєднаної дії дієтичної добавки Leptin

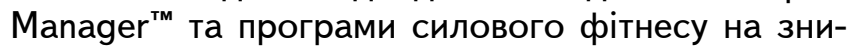
ження маси тіла жінок I та II періоду зрілого віку з різними генотипами.

Матеріали та методи дослідження. У дослідженні взяли участь 62 особи, з них експерементальна група склалася з 21 жінки II періоду зрілого віку з надлишковою масою тіла (IMT $\geq 25$ ), які брали участь у тренувальній програмі із силового фрітнесу на фоні одночасного прийому препарату «Лептин Менеджер». Контрольну групу склали 17 жінок, які займалися силовим фітнесом і не приймали препарат, та 24 жінки, які не займалися фрітнесом.
Для молекулярно-генетичного аналізу в нашій роботі використовували зразки ДНК, отримані шляхом змиву епітеліальних клітин ротової порожнини. Забір ДНК проводили за допомогою універсального зонду «ЗГУ-ЦМ». Ротову порожнину перед забором матеріалу попередньо промивали 0,9 \% розчином натрію хлориду. ДНК виділяли з букального епітелію за допомогою набору реактивів Diatom ${ }^{\mathrm{TM}}$ DNA Prep (Biokom) («Центр Молекулярной Генетики», Росія).

Q223R поліморфізм гена $L E P R$ визначали методом ПЛР у реальному часі за допомогою приладу «7500 Fast Real-time PCR» (Applied Biosystems, USA) 3 використанням TaqMan®Master Mix (2x) (Thermo Fisher Scientific, USA) (assay C_8722581_10). Визначення лептину проводили ензимним імунозв'язуючим імуносорбентним методом, побудованим за принципом сандвічу із використанням реактивів «Leptin Sandwich» фрірми «DRG» (Germany) на імуноферментному аналізаторі «Tecan Sunrise» (Австрія). Матеріал для досліджень отримували зі зразків крові з периферичної вени, взятої вранці у стані спокою натще без попереднього фрізичного навантаження.

Вимірювання обхватних розмірів різних частин тіла виконували за допомогою сантиметрової стрічки: окружність грудей (ОГ), окружність плеча (ОП), окружність талії (ОТ), окружність живота (ОЖ), окружність таза (ОТ), окружність стегна (ОС). На основі отриманих антропометричних показників розраховували індекс маси тіла (IMT). Композиційний склад тіла визначали на приладі «Tanita Body Composition Analyzer BC-418» методом біоелектричного імпендансу [59]. Досліджували такі показники: частку жировової тканини (\%, ЖТ), жирову масу, (кг, ЖМ), безжирову масу тіла (кг, БМТ), загальний вміст води (кг, ЗВВ).

Дослідження тривало 3 міс. (з жовтня до грудня 2017 р. включно) на базі фітнес-клубу «Інтерфіт», м. Київ. Програма дослідження передбачала первинне обстеження учасниць, анкетування, визначення антропометричних показників, обхватних розмірів та складу тіла (співвідношення жирової та м'язової маси тіла), генетичний аналіз, заняття оздоровчим фрітнесом за наданою програмою протягом 3 міс. Всі учасниці підписували інформовану згоду про участь у проекті та отримали рекомендації щодо раціонального харчування; індивідуальні рекомендації з тренувань, препарат «Лептин Менеджер», розрахований на тривалість курсу 12 тиж. (потижнево). Забір крові, букального епітелію та визначення композиційного складу тіла методом біоімпедансометрії за допомогою приладу «Tanita» проводили на базі 
науково-дослідного інституту Національного університету фрізичного виховання і спорту України. Виділення ДНК та детекцію генетичних поліморфрізмів виконували на базі лабораторії відділу загальної та молекулярної фрізіології інституту фрізіології ім. О. О. Богомольця НАН України.

Весь тренувальний процес було поділено на три тижні: легкий, силовий та інтенсивний. Тренування побудовано за системою Crossfit, функціонального тренінгу та включали роботу на тренажерах (блочні та важельні пристої) за системою Full-body у кожному тренуванні. Всі учасниці дотримувалися раціонального харчування. Кількість прийомів їжі з перекусами - 5-6 на день.

Препарат «Лептин Менеджер» (Xymogen, USA) - це дієтична добавка, одна капсула якої складається з 15 мг аскорбінової кислоти та 80 мг формули ORALVISC ${ }^{\circledR}$ (зареєстрована торгова марка), що представлена сумішшю глюкуронової кислоти та інших глікозаміногліканів). Мішенню препарату $\epsilon$ жирові клітини. Впливає на адипогенез і експресію генів адипогенних маркерів у мультипотентних клітинах, на рівень лептину та інших цито- та хемокінів у сироватці крові та синовіальній рідині та сприяє зниженню маси тіла.

Результати дослідження. Аналіз частоти зустрічі $Q / R$ поліморфізму гена лептинового рецептора (LEPR) (rs1137101) дозволяє стверджувати, що у групі жінок, які мають надлишкову масу тіла, частота зустрічі названого поліморфрізму $є$ вищою, ніж у європейській популяції. Так, у наших дослідженнях частота зустрічі Q/Q-генотипу становила $25 \%, Q / R-57 \%$, a R/R - $19 \%$. Частота алеля $\mathrm{Q}$ дорівнювала 0,53, тоді як алеля $\mathrm{R}-0,46$. Згідно з базою даних NCBI та ESEMBL, частота зустрічі алеля $A(Q)$ у світі становить 0,415 . Але різні популяції мають різну частоту зустрічі цього алеля. Так, за даними [5] досліджень Queabec Family Study, частота зустрічі алеля Q у британській, американській та фрранцузській популяціях становить 0,56, у датській - 0,56. У більш закритих популяціях цей алель виявляють рідше: 0,15 - у японців та 0,25 - у індіанців Ріта. Таким чином, частота $Q$-алеля у нашій вибірці була дещо знижена порівняно з європейською популяцією, що може бути наслідком відбору жінок до наших досліджень, оскільки основним критерієм цього відбору була наявність надлишкової маси тіла.

Визначення рівня лептину у венозній крові жінок 3 надлишковою масою тіла методом ELISA дозволило встановити, що цей показник характеризується широким розсіюванням від 3,55 до $41,86 \mathrm{Hг} \cdot \mathrm{Mл}^{-1}$, при середньому значенні $12,1 \pm 7,8 \mathrm{Hг}^{\cdot}$ мл $^{-1}$, що вдвічі перевищує середні показники для жінок $з$ нормальною масою тіла.
Оскільки референтними значеннями нормального вмісту лептину в крові жінок вважається діапазон 3,63-11,09 нг $\cdot \mathrm{m}^{-1}$, тому всіх жінок було поділено на три групи: з нормальним рівнем лептину, зі зниженим (4 \% осіб) і підвищеним (36 \%). Хоча більшість дослідників зазначають, що жінкам 3 ожирінням властивий високий рівень лептину [24], у нашій роботі це не підтверджено. Причинами такого розсіювання показників лептину можуть бути невраховані фрактори, а саме вплив поліморфізмів самого гена лептину та післясплайсингові процеси.

Результати дослідження концентрації лептину у крові демонструють знижений рівень лептину у жінок з генотипом R/R (рис. 1). Така особливість має характер тенденції і статистично не вірогідна. Але при порівнянні показників лептину у жінокносіїв Q-алеля (Q/Q- та Q/R-генотипи) із жінками-носіями RR-генотипу виявлено, що показник лептину у жінок-носіїв Q-алеля вдвічі вищий, ніж у жінок-носіїв RR-генотипу ( $p=0,045)$. Названа закономірність свідчить про те, що Q-алель може сприяти розвитку лептинової резистентності. Встановлене нами явище суперечить раніше встановленим постулатам про те, що R-алель сприяє розвитку лептинової резистентності $[5,10,19]$. Але існуючі відмінності можуть бути пояснені етнічними особливостями, оскільки більшість закономірностей було встановлено на острівних популяціях.

Підвищений рівень лептину мали $50 \%$ жінок 3 генотипом $Q / Q, 33 \%$ - 3 генотипом $\mathrm{Q} / \mathrm{R}, 11 \%$ - 3 генотипом R/R. Середня величина IMT у жінок з генотипом $Q / Q$ становила $30,78 \pm 3,11$, з генотипом $Q / R-31,37 \pm 5,8,3$ генотипом $R / R-27,4 \pm 2,72$ (рис. 2).

Хоча рівень лептину залежить від поліморфізму гена $L E P R$, але прямої залежності немає, тому що на цей показник можуть впливати й інші генетичні та метаболічні фрактори. Тому, обговорюючи значення визначення лептину як маркера генетичного дефіциту лептинових рецепторів, слід підкреслити, що рівень лептину у сироватці крові осіб з ожирінням змінюється непропорційно, отже його не можна використовувати як маркер десріциту рецепторів лептину.

Коефріцієнт парної кореляції Пірсона (r) між рівнем лептину та IMT становить 0,702 , тоді як між лептином і масою тіла - 0,648, а між лептином та вмістом жирової тканини у відсотках 0,73. Це свідчить про те, що між антропометричними показниками та рівнем лептину існує лінійний зв'язок; між лептином, IMT та відсотком жирової тканини - тісний зв'язок, між масою тіла та лептином - середнього ступеня зв'язок. 
Рівень лептину, нг.мл ${ }^{-1}$
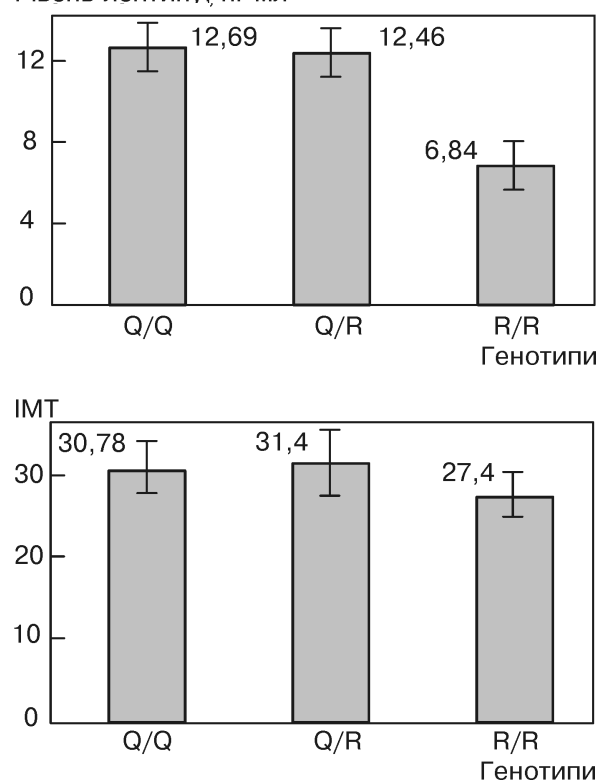

Таким чином, у роботі встановлено тісний лінійний зв'язок між рівнем лептину і такими показниками, як індекс маси тіла $(r=0,7)$ і вміст жирової тканини $(r=0,73)$; середнього ступеня зв'язок між рівнем лептину та масою тіла ( $r=$ 0,65). Жінки-носії $Q$-алеля та генотипа $Q / Q$ характеризуються вищим рівнем лептину, ніж носії $\mathrm{R} / \mathrm{R}$ - генотипу. Серед жінок з генотипом R/R вищий від норми рівень лептину зустрічається на $39 \%$ рідше, ніж 3 генотипом $Q / Q$.

Доведено, що лептин, хоча й змінюється під впливом фрізичних навантажень, але не пропорційно інтенсивності, тривалості фрізичних навантажень, а відповідно до індивідуальних метаболічних особливостей. У нашому дослідженні у всіх обстежуваних контрольної і експериментальної груп, рівень лептину змінився різнопланово. Сумарно рівень лептину знизився на 2,92 нг $\cdot \mathrm{мл}^{-1}$, що становило $13 \%$ вихідного рівня.

Під впливом препарату «Лептин Менеджер» спостерігалась тенденція до нормалізації рівня лептину в осіб, у яких він був підвищений. В експериментальній групі після прийому препарату та фрізичних навантажень рівень лептину знизився на 3,85 \pm 0,25 нг $\cdot$ мл $^{-1}$, що становило 33,4 \% (р < 0,05), а в контрольній групі - на $0,49 \pm 0,3 \mathrm{нг} \cdot \mathrm{мл}^{-1}$, що становило 6,1 \% початкового рівня (рис. 3).

В експериментальній групі у жінок з генотипом $Q / Q$ рівень лептину зріс на 0,14
Рівень лептину, нг·мл

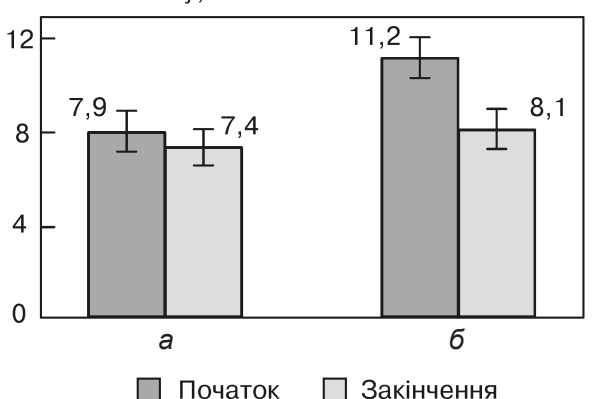

Рисунок 3 -

Рівень лептину у контрольній (a) та експериментальній (б) групах до та після

3 міс. силового фотнесу

нг м $^{-1}$, у жінок з Q/R-генотипом знизився на 5,47 нг мл $^{-1}$, а з R/R-генотипом - зменшився на 1,4 нг $\cdot$ мл $^{-1}$, що становить 21,2 \%. Тобто R-алель та R/R-генотип сприяють зниженню лептину після ффізичних навантажень.

В усіх групах після трьох місяців занять показники складу тіла змінились у напрямку нормалізації. Спостерігається широкий діапазон індивідуальних варіацій антропометричних показників. У контрольній групі маса тіла зменшилася (у середньому на 2 кг), ІМТ зменшився на 4 \%, вміст жиру знизився з 32 до $29 \%$ (на $3 \%$ ), вміст вісцерального жиру не зменшився, тоді як в експериментальній групі маса тіла зменшилася на $5 \%$, а вміст жиру - з 36 до $34 \%$ (на $2 \%$ ), вміст вісцерального жиру - на $2 \%$ за рахунок збільшення відсотку м'язової маси (табл. 1).

Більш значні зміни обхватних розмірів також спостерігали в експериментальній групі (табл. 2).

Результати змін показників під впливом орізичних навантажень (рис. 4) свідчать, що найбільші зміни відбулися у жінок експериментальної групи.

У підгрупах жінок, поділених за генотипом в експериментальній групі, під впливом фрізичних навантажень та прийому препарату відбулись однакові за напрямом, але різні за амплітудою зміни. Маса тіла у жінок з Q/Q-генотипом знизилася на 5,8 \%, з Q/R-генотипом - на $4 \%$, з R/R-генотипом - на 6,1 \%. IMT найбільше знизився у жінок з Q/Q-генотипом (на $7 \%$ ); найбільші

ТАБЛИЦЯ 1 - Антропометричні показники жінок експериментальної та контрольної груп до та після 3 міс. силового фітнесу

\begin{tabular}{|l|c|c|c|c|}
\hline \multirow{2}{*}{\multicolumn{1}{c|}{ Показник }} & \multicolumn{3}{|c|}{ Група } \\
\cline { 2 - 5 } & \multicolumn{2}{|c|}{ експериментальна } & \multicolumn{2}{c|}{ контрольна } \\
\cline { 2 - 5 } & початок & закінчення & початок & закінчення \\
\hline Маса тіла, кг & $82,1 \pm 12,8$ & $78,10 \pm 12,14$ & $75,7 \pm 14,84$ & $73,52 \pm 15,16$ \\
ІМТ & $30,31 \pm 5,19$ & $28,80 \pm 4,71$ & $27,5 \pm 4,5$ & $26,3 \pm 4,01$ \\
Частка жирової маси, \% & $36,27 \pm 6,5$ & $34,85 \pm 6,71$ & $31,65 \pm 7,34$ & $29,75 \pm 6,8$ \\
Частка м'язової маси, \% & $48,89 \pm 5,09$ & $49,77 \pm 5,96$ & $48,55 \pm 4,0$ & $48,2 \pm 6,5$ \\
Частка вісцерального жиру, \% & $7,14 \pm 3,02$ & $5,13 \pm 2,31$ & $4,5 \pm 2,3$ & $4,0 \pm 2,8$ \\
Метаболічний вік, роки & $47,36 \pm 12,63$ & $46,06 \pm 12,57$ & $35,66 \pm 8,51$ & $34,00 \pm 11,31$ \\
\hline
\end{tabular}


ТАБЛИЦЯ 2 - Показники обхватних розмірів жінок експериментальної та контрольної груп до та після 3 міс. силового фітнесу

\begin{tabular}{|l|c|c|c|c|}
\hline \multirow{2}{*}{\multicolumn{1}{c|}{ Показник }} & \multicolumn{4}{|c|}{ Група } \\
\cline { 2 - 5 } & \multicolumn{2}{|c|}{ експериментальна } & \multicolumn{2}{c|}{ контрольна } \\
\cline { 2 - 5 } & до & після & до & після \\
\hline Окружність грудей & $104,68 \pm 10,46$ & $101,75 \pm 11,308$ & $100,5 \pm 9,25$ & $99,75 \pm 9,7$ \\
\hline Окружність талії & $89,50 \pm 11,46$ & $86,93 \pm 11,64$ & $81,00 \pm 9,09$ & $79,25 \pm 8,99$ \\
\hline Окружність живота & $102,59 \pm 13,5$ & $96,55 \pm 12,31$ & $95,5 \pm 12,6$ & $94,00 \pm 12,46$ \\
\hline Окружність таза & $112,32 \pm 9,04$ & $108,06 \pm 8,5$ & $110,25 \pm 9,61$ & $108,0 \pm 8,3$ \\
\hline Окружність плеча & $34,80 \pm 3,42$ & $33,23 \pm 2,8$ & $32,5 \pm 4,2$ & $31,75 \pm 3,77$ \\
\hline Окружність стегна & $66,55 \pm 6,8$ & $64,68 \pm 6,6$ & $64,75 \pm 5,05$ & $64,25 \pm 5,85$ \\
\hline
\end{tabular}

зміни відсотку жирової маси належать жінкам 3 R/R-генотипом. Найбільші зміни відсотку вісцерального жиру - жінкам 3 R/R-генотипом (17\%). Таким чином, найбільш інтенсивні зміни у композиційному складі тіла відбулися у жінок $3 \mathrm{R} / \mathrm{R}$-генотипом.

\section{Висновки}

1. До причин, що викликають аліментарне ожиріння, належать гіподинамія, генетичні фрактори, неправильне харчування, порушення харчової поведінки. Внесок генетичних факторів у розвиток ожиріння оцінюють від 30 до 70 \%. Ряд поліморфізмів гена лептину $(L E P)$ та лептинового рецептора ( $L E P R)$ асоційовані з розвитком ожиріння. Q223R поліморфізм гена LEPR може слугувати молекулярно-генетичним маркером лептинової резистентності і сприяти розвитку ожиріння.

2. Рівень лептину у жінок з надмірною масою тіла характеризується широким діапазоном, що перевищує норму у бік як низьких, так і високих концентрацій: 4 \% жінок рівень лептину був нижчий від норми, 36 \% - вищий від норми.

3. Встановлено тісний лінійний зв'язок між рівнем лептину і такими показниками, як індекс маси тіла $(r=0,7)$ і вміст жирової тканини $(r=0,73)$; середнього ступеня зв'язок між лептином та масою тіла $(r=0,65)$. Жінки носії $\mathrm{Q}$-алеля та генотипу $\mathrm{Q} / \mathrm{Q}$ характеризуються вищим рівнем лептину, ніж носії R/R-генотипу. Серед жінок з генотипом R/R підвищений рівень лептину зустрічається на $39 \%$ рідше, ніж 3 генотипом $Q / Q$.

4. Фізичні навантаження призвели до незначного зниження рівня лептину: в експериментальній групі - на 33,4 \% (р < 0,05), у контрольній на 6,1 \%. R-алель та $\mathrm{R} / \mathrm{R}$-генотип гена $L E P R$ сприяють зниженню рівня лептину після фрізичних навантажень. Вживання препарату «Лептин Менеджер» призводить до вірогідного зменшення рівня лептину порівняно з контрольною групою.

5. Поєднаний вплив тренувальної програми силового фрітнесу та вживання препарату «Лептин Менеджер» призводять до більш значних змін антропометричних показників, композиційного складу тіла жінок з надмірною масою тіла порівняно $з$ контрольною групою. Найбільш інтенсивні зміни у композиційному складі тіла відбулися у жінок з R/R-генотипом гена LEPR.

Перспективи подальших досліджень. У подальшому дослідженні буде встановлено вплив цього препарату на експресію генів, які контролюють жировий та вуглеводний обміни, що дозволить розробити рекомендації для вживання цього препарату особам із надлишковою масою тіла та ожирінням при підвищеному рівні лептину та індивідуалізувати прийом препарату особам із різними генотипами.
Приріст, см

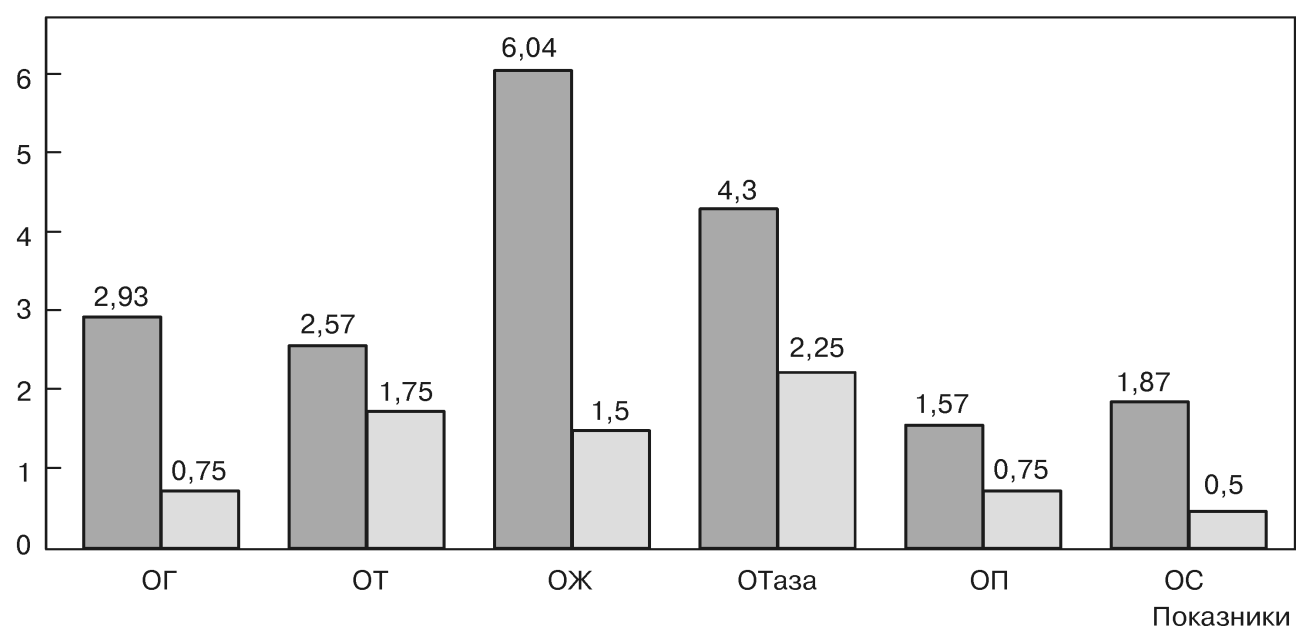

Рисунок 4 - Приріст обхватних розмірів у жінок експериментальної ( $\square)$ i контрольної ( $\square$ груг 


\section{References}

1. Algul, S., Ozdenk, C., Ozcelik, O. (2017).Variations in leptin, nesfatin-1 and irisin levels induced by aerobic exercise in young trained and untrained male subjects. Biol. Sport, 34(4), 339-344.

2. Bell, C.G., Walley, A.J., Froguel, P. (2005). The genetics of human obesity. Nat. Rev. Genet., 6, 221-234.

3. Bostrom, P., Wu, J., Jedrychowski, M.P., Korde, A., Ye, L., Lo, J.C., Rasbach, K.A., et al. (2012). A PGC1-a-dependent myokine that drives brown-fat-like development of white fat and thermogenesis. Nature, 481(7382), 463-468.

4. Bouchard, C. (2008). Physical activity and obesity.

5. Chagnon, Y.C., Chung, W.K., Pérusse, L., Chagnon, M., Leibel, R.L., Bouchard, C. (1999). Linkages and associations between the leptin receptor (LEPR) gene and human body composition in the Québec Family Study. Int. J. Obes. Relat. Metab. Disord, 23(3), 278-286.

6. Comuzzie, A.G., Allison, D.B. (1998). The search for human obesity genes. Science, Vol. 280, 1374-1377

7. Considine, R.V., Considine, E.L., Williams, C.J., Hyde, T.M., Caro, J.F. (1996). The hypothalamic leptin receptor in humans: identification of incidental sequence polymorphisms and absence of the $\mathrm{db} / \mathrm{db}$ mouse and fa/ fa rat mutations. Diabetes, 45 (7), 992-4.

8. Diamond, F.B., Eichler, D.C. (2002). Leptin and the adipocyte endocrine system. Crit. Rev. Clin. Lab. Sci., 39(4-5), 499-525

9. Dunstan, J., Bressler, J.P., Moran, T.H., Pollak, J.S., Hirsch, A.G., Bailey-Davis, L., Glass, T.A., Schwartz, B.S. (2017). Associations of LEP, CRH, ICAM-1, and LINE-1 methylation, measured in saliva, with waist circumference, body mass index, and percent body fat in mid-childhood. Clinical Epigenetics, Vol. 9, N 29. DOI 10.1186/s13148-017-0327-5.

10. Fan Sook-Ha, Say Yee-How (2014). Leptin and leptin receptor gene polymorphisms and their association with plasma leptin levels and obesity in a multi-ethnic Malaysian suburban population. Journal of Physiological Anthropology, 33, 15

11. Fantuzzi, G., Faggioni, R. (2000). Leptin in the regulation of immunity, inflammation, and hematopoiesis. J. Leukoc. Biol, 68, 437-446.

12. Jürimäe, J., Mäestu, J., Jürimäe, T., Mangus, B., von Duvillard, S.P. (2011). Peripheral signals of energy homeostasis as possible markers of training stress in athletes: a review. Metabolism, 60(3), 335-350.

13. Lakka, T.A., Rankinen, T., Weisnagel, S.J., Chagnon, Y.C., Lakka, H.M., Ukkola, O., Boulé, N., et al. (2004). Leptin and leptin receptor gene polymorphisms and changes in glucose homeostasis in response to regular exercise in nondiabetic individuals: the HERITAGE family study. Diabetes, 53 (6), 1603-1608

14. Lenard, N.R., Berthoud, H.R. (2008). Central and peripheral regulation of food intake and physical activity: pathways and genes. Obesity (Silver Spring), 16, Suppl. 3, 11-22.

15. Leońska-Duniec, A., Ahmetov, I.I., Zmijewski, P. (2016). Genetic variants influencing effectiveness of exercise training programmes in obesity - an overview of human studies. Biol. Sport, 33(3), 207-214.

16. Loos, R.J., Bouchard, C. (2003). Obesity: is it a genetic disorder? J. Int. Med., Vol. 254, 401-425

17. Li, S., Zhao, J.H., Ekelund, U., et al. (2010). Physical activity attenuates the genetic predisposition to obesity in 20,000 men and women from EPIC: Norfolk prospective population study. PloS Med., Vol. 7, 9.

18. Mărginean, C., Oana Mărginean, C., lancu, M., Melit, L.E., Tripon, F., Bănescu, C. (2016). The FTO rs9939609 and LEPR rs1137101 mothers-newsdrozdoska@gmail.com borns gene polymorphisms and maternal fat mass index effects on anthropometric characteristics in newborns. Medicine, Vol. 95, 49, 1-10.

19. Messaoudi, I., Handu, M., Rais, M., Sureshchandra, S., Park, B.S. Fei, S.S., Wright, H., et al. (2017). Long-lasting effect of obesity on skeletal muscle transcriptome. BMC Genomics, 18, 411

20. Murakami, H., lemitsu, M., Fuku, N., Sanada, K., Gando, Y. (2014). The Q223R polymorphism in the leptin receptor associates with objectively measured light physical activity in free-living. Japanese Physiology \& Behavior, 129, 199-204.

21. Ozcelik, O., Dogan, H., Celik, H., Ayar, A., S., Serhatlioglu, Kelestimur, H. (2005). Effects of different weight loss protocols on serum leptin levels in obese females. Physiol. Res., 54(3), 271-277.

22. Rankinen, T., Zuberi, A., Chagnon, Y.C., et al. (2006). The human obesity gene map: the 2005 update. Obesity (Silver Spring), Vol. 14, 529-644.

23. Rankinen, T., Bouchard, C. (2007). Invited commentary: Physical activity, mortality, and genetics. American Journal of Epidemiology, Vol. 166, 260-262.

24. Remmel, L., Tillmann, V., Purge, P., Lätt, E., Jürimäe, J. (2017). Associations of serum leptin, ghrelin and peptide YY levels with physical activity and cardiorespiratory fitness in adolescent boys with different BMI values. Biol. Sport, 34 (4), 345-352.

25. Rojano-Rodriguez, M.E., Beristain-Hernandez, J.L., Zavaleta-Villa, B., Maravill, P., Romero-Valdovinos, M., Olivo-Diaz, A. (2016). Leptin receptor gene polymorphisms and morbid obesity in Mexican patients. Hereditas, 153, 2.

26. Salehzadeh, K., Agaziyev, A. (2011). Does regular aerobic training affect basal leptin level (difference between male and female)? African Journal of Microbiology Research, 5(31), 5591-5595.

27. Soubry, A., Schildkraut, J.M., Murtha, A., Wang, F., Huang, Z., Bernal, A., et al. (2013). Paternal obesity is associated with IGF2 hypomethylation in newborns: results from a Newborn Epigenetics Study (NEST) cohort. BMC Med., 11, 29.

28. Uysal, N., Agilkaya, S., Sisman, A.R., Camsari, U.M., Gencoglu, C., Dayi, A., Aksu, I., Baykara, B., Cingoz, S., Kiray, M. (2017). Exercise increases leptin levels correlated with IGF-1 in hippocampus and prefrontal cortex of adolescent male and female rats. J. Chem. Neuroanat., 4 (81), 27-33.

29. Voss, S.C., Nikolovski, Z., Bourdon, P.C., Alsayrafi, M., Schumacher, Y.O. (2016). The effect of cumulative endurance exercise on leptin and adiponectin and their role as markers to monitor training load. Biol. Sport, 33(1), 23-28.

30. Walsh, S., Haddad, C.J., Kostek, M.A., Angelopoulos, T.J., Clarkson P.M., Gordon, P.M., et al. (2012). Leptin and leptin receptor genetic variants associate with habitual physical activity and the arm body composition response to resistance training. Gene, 510, 66-70.

31. Wardle, J., Carnell, S., Haworth Claire, M.A., et al. (2008). Evidence for a strong genetic influence on childhood adiposity despite the force of the obesogenic environment. Am. J. Clinical Nutrition, Vol. 87, 398-404.

32. Wauters, M., Considine, R.V., van Gaal, L.F. (2000). Human leptin: from an adipocyte hormone to an endocrine mediator. Eur. J. Endocrinol., 143, 293-311.

33. http://www.genecards.org/cgi-bin/carddisp.pl?gene = LEPR

34. https://www.ncbi.nlm.nih.gov/projects/SNP/snp_ref.cgi?rs = 1137101

35. http://www.who.int/en/

36. http://www.ukrstat.gov.ua/ 